УДК 372.891(857)

dx.doi.org/10.24866/7444-4911-7/16-19

\title{
Интеграция в изучении дисциплин «География» и «Биология» на примере урока «Флора и фауна Дальнего Востока»
}

\section{И.Ф. Коломеец, Н.В. Быковская, С.С. Перелыгина}

Дальневосточный федеральный университет. Филиал в г. Уссурийске (Школа педагогики)

Обсуждается интегрированный урок с точки зрения преподавания географии и биологии.

Ключевые слова: интеграция дисциплин «География» и «Биология», интегрированный урок, фрлора и фрауна Дальнего Востока.

Содержание школьных дисциплин «География» и «Биология», раскрывающих характер и динамику географических и экологических процессов, а также понимание сущности взаимодействия природы и общества, характеризуется интеграцией знаний, приоритетом экологического воспитания. Связующим звеном между содержанием школьной биологии и географрии является изучение распространения живых организмов согласно природной зональности, изучение биоразнообразия в связи с условиями существования, изучение жизнедеятельности живых организмов под действием абиотических, биотических и антропогенных экофракторов (Бекетова и др., 2014).

Такие школьные предметы, как география и биология, обладают широким диапазоном межпредметных связей, имеют разнообразие форм и средств обучения. Установление межпредметных связей в школьном курсе способствует более полному усвоению знаний, развитию логического мышления и творческих способностей учащихся.

В настоящее время в практике преподавания используют интегрированные уроки, которые создают благоприятные условия для формирования общеучебных знаний, умений и навыков обучающихся, повышают эффективность практической направленности обучения. Интегрированный урок - это объединение, взаимопроникновение знаний из области различных предметов по определённой теме. Интеграция помогает сблизить предметы, найти точки соприкосновения, более глубоко и в большем объёме преподнести содержание дисциплин. Интегрированный урок чаще всего проводится с целью изучения, закрепления и обобщения материала по определённой теме.

Широкое использование краеведческого материала, воспитание любви к родной природе и земле возможно в интегрированных уроках по географии ибиологии(Иванова, Костыгова, 1995; Крылова, 2000; Сухаревская, 2003; Болотникова, 2004; Медиаматериал..., 2020).

Нашей целью была разработкаинтегрированного урока по теме «Флора и фауна Дальнего Востока» для учащихся 8 класса.

Цели урока:

- сформировать образ Дальнего Востока;

-определить географическое положение Дальнего Востока;

- рассмотреть животный и растительный мир Дальнего Востока;

- сформировать отношение к Дальнему Востоку как уникальной территории России.

Тип урока: изучение нового материала.

Методы: частично-поисковый, объяснительно-иллюстративный.

Средства обучения: карты: «Физическая карта России», «Природа Дальнего Востока», 
учебники, атласы, компьютерная техника.

Ход урока

Организационный момент

Зачитывается стихотворение Ирины Лариной (2010) для выявления темы урока.

От Амура вдоль Уссури, вдоль Уссури до Амура

Самобранку расстелила полновластная тайга.

И гуляет тигр амурский, и медведь гуляет бурый,

И железная дорога - южной веткой пролегла.

Как не ехать, как не мчаться возле Сихотэ-Алиня,

Где пушистых сопок шапки подпирают облака,

И земля, как на ладони, раскрывает нам долины,

Где медведя или тигра - спрятан след наверняка.

Все дары свои природа разложила полной чашей;

Перевиты виноградом ель аянская и кедр,

Грудь земли пропахла мёдом - разнотравье вровень чаще,

И несметные богатства хоронятся в брюхе недр.

Больше тигр тут не хозяин, и медведю нет покоя,

И нарушена навеки тишина твоя, тайга.

Уступай Земля родная, едут новые Герои -

Надо строить человеку магистрали, города.

Очень хочется, ребята, всюду славить землю нашу,

Защитить её просторы и любовью, и трудом.

И у Сихотэ-Алиня заварить такую « кашу »,

Чтобы тигру и медведю,

и, конечно, человеку

был уютным этот Дом!

Скажите, о каком районе России данное стихотворение?

Сегодня изучим на уроке животный и растительный мир Дальнего Востока.

Каждый составляет конструктивную карточку в тетради: «Что я знаю?», «Что я узнал?»

1. Давайте вспомним, географическое положение Дальнего Востока и каждый назовёт по порядку пять географических объектов, которые находятся на территории Дальнего Востока (реки, озёра, низменности, горы, и т.д.).

2. Рассказ учителя о природе Дальнего Востока.

Растительный и животный мир Дальнего Востока гораздо богаче, чем в соответствующих по зональным условиям районах Сибири и европейской части России. Здесь много реликтовых растений и редких животных. Причин тому много, главные из них: огромная протяженность с севера на юг, слабое проявление ледниковой деятельности в четвертичном периоде, постоянное территориальное единство с остальной Азией и прошлое соединение Азии с Америкой в районе Берингова пролива (Инфоурок, 2015).

Обилие влаги в летнее время способствует развитию мощного растительного покрова. Большую часть территории Приморья занимает знаменитая уссурийская тайга, в которой самым причудливым образом сочетаются хвойные и широколиственные породы. Кедр и лиственница растут рядом с маньчжурским орехом и амурским бархатом. В лесах края произрастает свыше 250 видов деревьев и кустарников. Приморье занимает одно из первых мест в России по числу эндемиков - растений, распространенных лишь в данном районе. Только здесь растут амурский бархат (пробковое дерево), женьшень, маньчжурский орех, амурский виноград, лимонник, железная береза и др. Много в крае и реликтовых растений, сохранившихся еще с неогена.

Разнообразен и богат животный мир Приморья. К эндемикам относятся уссурийский 
тигр, кожистая черепаха, к остаткам фрауны неогена и четвертичного периода принадлежат пятнистый олень, гималайский медведь, амурская антилопа горал, маленькая изящная уткамандаринка, поражающая красотой своего оперения, земляной дрозд и др.

3. На Дальнем Востоке три типа фрлор и фаун: Маньчжурская, Восточно-Сибирская, Охотско-Камчатская (Швецова,2006).

Давайте разделимся на 3 группы и каждая группа расскажет о геоположении одного из типов, а также его составляющую - фллору и фауну.

Для подготовки в группе даётся 7 минут, материал берётся в учебнике, атласе.

Геоположение каждого типа показывает представитель группы у доски на карте «Физическая карта России».

1 группа. Маньчжурская.

Находится в среднем Амуре с его притоками, бассейн реки Уссури, юг и юго-восток Приморья.

Растения: корейская кедровая сосна, бархат амурский, дубмонгольский, липа амурская, орех маньчжурский, клён.

Животные: амурский тигр, гималайский медведь, изюбрь, енотовидная собака, дальневосточный аист, дальневосточная квакша.

2 группа. Восточно-Сибирская.

Находится в бассейне Верхнего и Среднего Амура и к северу от него.

Растения: Лиственница даурская, кедровый стланик, ель сибирская.

Животные:Бурый медведь, соболь, лось, косуля, каменный глухарь, заяц-беляк.

3 группа. Охотско-Камчатская.

Находится в горах Среднего Приамурья, в горных хребтах Сихотэ-Алиня, на Охотском побережье, на Сахалине, Курильских островах, Камчатке.

Растения:ель аянская, пихта белокорая, каменная берёза, сахалинская пихта.

Животные: кабарга, уссурийский снегирь, дикуша, чёрный журавль, камчатский сурок.

Учитель при назывании представителей фрлоры и фрауны, показывает их в презентации.

После ответов каждой группы следует отвлечься.

Физкультминутка.

Давайте немного отвлечёмся, отдохнём. Встаньте напротив друг друга. Поприветствуем друг друга так, как это принято у соседей Дальневосточного региона.

Россия - пожимаем друг другу руки;

Япония, КНДР - лёгкий поклон на $15^{\circ}$, при этом мальчики прижимают руки к телу, девочки складывают руки вместе впереди;

Китай - подняв над головой сцепленные руки;

США - с расстояния машут рукой, можно улыбнуться и подмигнуть друг другу.

Отдохнули, снова примемся за работу.

Закрепление знаний.

Тестовая работа с самопроверкой.На слайде выводится тест:

1. Какого типа фрлоры и фрауны на Дальнем Востоке нет?

а) Маньчжурского; б) Восточно-Сибирского; в) Европейского; г) Охотско-Камчатского.

2. Какое море не омывает Дальний Восток?

а) Японское; б) Жёлтое; в) Охотское; г) Чукотское.

3. Кто относится к эндемикам Дальнего Востока?

а) лиса серая; б) тигр амурский; в) ласка китайская; г) олень пятнистый;

4. Утка-мандаринка - это

а) эндемик; б) реликт

5. Что не относится к Охотско-Камчатской фрлоре?

а) ель аянская; б) кедровый стланик; в) каменная берёза; г) сахалинская пихта.

Рефлексия.

Заполнение конструктивной карточки «Что я узнал».

Домашнее задание: 
1. Изучить раздел «Дальний Восток» учебника (Домогацких, Алексеевский, 2015).

2. Посмотреть фильм: «Флора и фауна. Дальний восток»

Таким образом, разработанный интегрированный урок по географии и биологии предназначен для изучения, закрепления и обобщения материала по теме«Флора и фауна Дальнего Востока». На уроке предусматривается смена видов деятельности обучающихся, использование технических средств (показ слайдов, просмотр фрильма), выполнение заданий на закрепление изученного. Урок способствует развитию интересов учащихся в области краеведения.

\section{Литература}

Бекетова С.И., Камахина Р.С., Лохотская Л.А. Интеграция учебных предметов «География» и «Биология» как условие фоомирования научного мировоззрения учащихся // Современные проблемы науки и образования. 2014. № 1. С. 42.

Болотникова Н.В. География. Интегрированные уроки. 6-10 классы. Волгоград: Изд-во «Учитель», 2004. $100 \mathrm{C}$.

Домогацких Е.М., Алексеевский Н.И. География: физическая география России: Учебник для 8 класса общеобразовательных организаций. М.: ООО «Русское слово - учебник», 2015. 344 с.

Иванова Г.Ф., Костыгова М.Ю. Интеграция в процессе обучения географии и биологии // География в школе. 1995. № 5. С. 60.

Инфоурок, 2015. Конспект урока по географии «Пространство Дальнего Востока». Режим доступа: https://infourok.ru/konspekt-uroka-po-geografii-prostranstvo-dalnego-vostoka-2467382.html.

Крылова О.В. Интересный урок географии: Кн. для учителя. М.: Просвещение, 2000. 95 с.

Ларина И. Здесь хозяин человек // Дальний Восток- стихи о родном крае, 2010. Режим доступа: https://ljubimaja-rodina.ru/stikhi/242-dalnij-vostok-stikhi-o-rodnom-krae.html.

Медиаматериал «Флора и фрауна. Дальний восток». Режим доступа: https://www.youtube.com/watch?v=HzTxqNN ZEA. 2020.

Сухаревская Е.Ю. Технология интегрированного урока. Ростов н/Д: Изд-во «Учитель», 2003.

Швецова В.А. Презентация - Растительный и животный мир лесов Дальнего Востока, разработана на основе авторской программы Л.Е. Дмитриевой и Л.Г. Колесниковой (Благовещенск, 2006 г.). Режим доступа: https://topslide.ru/jekologija/rastitielnyi-i-zhivotnyi-mir-liesov-dalniegho-vostoka.

\section{Integration in the study of the disciplines "Geography» and «Biology» on the example of the lesson «Flora and fauna of the Far East»}

\section{I.F. Kolomeets, N.V. Bykovskaya, N.V. Perelygina}

Far Eastern Federal University. Branch in the Ussuryisk city (School of pedagogics)

An integrated lesson is discussed from the point of view of teaching geography and biology.

Keywords: integration of disciplines "Geography» and «Biology», integrated lesson, flora and fauna of the Far East.

\section{Сведения об авторах:}

Коломеец Ирина Федоровна - администратор образовательных программ филиала ДВФУ в г. Уссурийске (Школы педагогики). 692500, Приморский край, г. Уссурийск, ул. Некрасова, 35. E-mail: i_r_i_n_a2000@mail.ru;

Быковская Наталья Владимировна - к.б.н., доцент кафедры естественнонаучного образования фрилиала ДВФУ в г. Уссурийске (Школы педагогики). 692500, Приморский край, 2. Уссурийск, ул. Некрасова, 35. E-mail: bykovskaya_1968@mail.ru

Перелыгина Серафима Сергеевна - студент бакалавриата, кафредра естественнонаучного образования филиала ДВФУ в г. Уссурийске (Школа педагогики).

E-mail: persima20000@gmail.com. 